\title{
ANNA ZELLMA \\ [Nie]wymierna rola rodziców w stymulowaniu aktywności poznawczej dziecka
}

Analizy dotyczące roli rodziny w integralnym wychowaniu dziecka są prowadzone od dawna. W ostatnich latach wzrasta jednak zainteresowanie tą problematyką. Badacze zwracają uwagę na różne aspekty zaangażowania rodziców w proces integralnego wychowania dzieci ${ }^{1}$. Konsekwentnie wskazują na działania opiekuńczo-wychowawcze wywołane nowymi potrzebami społecznokulturowymi ${ }^{2}$. Przemiany zachodzące w społeczeństwie i kulturze w znacznym stopniu warunkują bowiem całość zachowań oraz postaw rodziców wobec dziecka, jego rozwoju, socjalizacji i edukacji. Niejednokrotnie prowadzą do zmiany roli rodziców w procesie wychowania dziecka. Wychodząc naprzeciw wyzwaniom społeczno-kulturowym, rodzice angażują się w poszukiwanie nowych form edukacji ${ }^{3}$. Coraz częściej kierują się modą i popularnością, rezygnując $\mathrm{z}$ tradycyjnych form wsparcia dzieci $\mathrm{w}$ rozwoju ${ }^{4}$. Stąd też niejednokrotnie wybierają nowoczesne propozycje, które są reklamowane w środkach społecznego przekazu oraz promowane przez nauczycieli, pedagogów i psychologów, a niekiedy

Anna ZELMA - prof. dr. hab., kierownik Katedry Teologii Pastoralnej i Katechetki Wydziału Teologicznego Uniwersytetu Warmińsko-Mazurskiego w Olsztynie, e-mail: anna.zellma@ uwm.edu.pl

${ }^{1}$ Zob. np. U. Dudziak: Życie, rodzina, wychowanie. Warszawa 2009; B. Muchacka (Red.): Rodzina w kontekście wspótczesnych problemów wychowania. Kraków 2008; Rodzina podmiotem wychowania i kreatorem komunikacji społecznej. Red. N. Pikuła. Kraków 2010.

${ }^{2}$ Zob. np. Rodzina w pierwszym dwudziestoleciu XXI wieku: problemy stare $i$ nowe. Red. E. Lubina. Lublin 2013.

${ }^{3}$ Zob. np. Rodzina wobec wyzwań wspótczesności. Red. A. Cudo, N. Kopeć, K. Sawicki. Lublin 2013; Rodzina w obliczu wspótczesnych wyzwań cywilizacyjnych. Red. H. Marzec, K. Szymczyk. T. 1. Piotrków Trybunalski 2013.

${ }^{4}$ Zob. np. Rodzina przestrzenia rozwoju osoby: perspektywa pedagogiczna. Red. M. Jeziorański, D. Opozda, A. Rynio. Lublin 2012. 
także przez znajomych ${ }^{5}$. W tym kontekście pojawiają się pytania: Jaką rolę odgrywają rodzice $\mathrm{w}$ stymulowaniu aktywności poznawczej dziecka? Na ile i w jaki sposób zapewniają dziecku optymalny rozwój? Jakie znaczenie ma zaangażowanie rodziców w stymulowanie aktywności poznawczej dziecka?

Poszukując odpowiedzi na wyżej postawione pytania, trzeba najpierw doprecyzować terminy „stymulowanie” i ,aktywność poznawcza”. Pozwoli to uniknąć braku precyzji w szczegółowych analizach dotyczących jakościowo i ilościowo zróżnicowanego zaangażowania rodziców w procesie stymulowania aktywności poznawczej dziecka. Osobną uwagę poświęci się mocnym i słabym stronom tego rodzaju roli rodzicielskiej. Wybór określonych form stymulowania aktywności poznawczej dziecka w znacznym stopniu decyduje o jakości zaangażowania rodziców w tym procesie.

\section{Wokół rozumienia kluczowych terminów}

Terminy „stymulowanie” i ,aktywność poznawcza” są powszechnie stosowane w różnych kontekstach edukacyjnych, wychowawczych, zawodowych. Można je zatem potraktować jako kategorie bliskie doświadczeniom rodziców. W literaturze przedmiotu dominują krótkie opisy zachowań typowych dla stymulowania i aktywności poznawczej ${ }^{6}$.

Powszechnie przyjmuje się, że termin „stymulowanie” wiąże się wprost $\mathrm{z}$ aktywnością człowieka ${ }^{7}$. Często łączony jest z dopełniaczem, który wskazuje na rodzaj tego działania. Zazwyczaj termin ,stymulowanie” oznacza ,pobudzanie do działania lub rozwoju"8. Traktowany jest jako czynność o charakterze bodźca wzmacniającego proces aktywności zewnętrznej i wewnętrznej osoby w określonych sferach osobowości (np. umysłowej, emocjonalnej, werbalnej, sensomotorycznej) ${ }^{9}$. Tak określone stymulowanie polega głównie na inicjowaniu warunków, które skłaniają konkretne osoby (np. dzieci, młodzież, dorosłych) do samodzielnego działania $\mathrm{w}$ celu realizacji określonych zadań ${ }^{10}$. Z punktu widze-

${ }^{5}$ Zob. więcej o tym np. w: A.J. Dudek: Chiński, joga i szachy - przedszkola kusza zajęciami dodatkowymi, by dać dzieciom ,,lepszy start”. http://natemat.pl/115069,chinski-joga-i-szachyprzedszkola-kusza-zajeciami-dodatkowymi-by-dac-dzieciom-lepszy-start (dostęp: 30.05.2016).

${ }^{6}$ Zob. np. Psychologiczne portrety czlowieka. Praktyczna psychologia rozwojowa. Red. A.I. Brzezińska. Gdańsk 2005; B. Muchacka: Stymulowanie aktywności poznawczej dzieci w przedszkolu. Kraków 2000; Aktywność poznawcza podmiotu w perspektywie badań kognitywistycznych. Red. A. Przybysz. Poznań 2015; I. Sikorska. Rozwój dziecka w przedszkolu. Stymulujące właściwości wybranych systemów edukacyjnych. Kraków 2010.

${ }^{7}$ Zob. np. tamże; Aktywność dzieci i młodzieży. Red. S. Guz, T. Sokołowska-Dzioba, A. Pielecki. Warszawa 2008.

${ }^{8} \mathrm{http} / / /$ sjp.pwn.pl/slowniki/stymulowa\%C4\%87.html (dostęp: 1.06.2016).

${ }^{9}$ Tamże.

${ }^{10}$ Tamże. 
nia wychowania $\mathrm{w}$ rodzinie zakres znaczeniowy wyżej opisanego terminu nie różni de facto w swojej treści. Odnosi się jednak głównie do zaangażowania rodziców w proces doskonalenia integralnego rozwoju dziecka. Wskazuje bowiem na udział rodziców w odpowiednim stwarzaniu sytuacji, które zachęcają do podejmowania aktywności poznawczej. W praktyce dokonuje się to m.in. poprzez wykorzystanie różnych form, metod i środków wychowawczych, które rodzice dobierają w celu wyzwalania u dziecka zewnętrznej i wewnętrznej gotowości do wielostronnej aktywności, a więc poznawczej i emocjonalnej sprzężonej z działaniem praktycznym. Aktywność ta znajduje wyraz w różnych czynnościach i zachowaniach ${ }^{11}$, wynikających zarówno $z$ wewnętrznych potrzeb i osobistych zainteresowań, jak też z zadań stawianych przez innych ${ }^{12}$.

Kluczem do właściwego zrozumienia terminu „stymulowanie” jest dookreślenie rodzaju działania, które wskazuje na jakość aktywności. W analizach podjętych w niniejszym tekście ( $\mathrm{z}$ uwagi na problem określony w tytule) za punkt odniesienia należy przyjąć indywidualną właściwość człowieka, jaką jest aktywność poznawcza ${ }^{13}$. Stanowi ona jedną $z$ wielu form jego aktywności własnej ukierunkowanej na dążenie do zaspokajania ciekawości poznawczej i potrzeb poznawczych lub wykonywania zadań o charakterze poznawczym ${ }^{14}$. Aktywności tej towarzyszy pozyskiwanie i przetwarzanie wiedzy oraz dążenie do poznania zjawisk nieznanych, wzbudzających zainteresowanie, spostrzeganych za pomocą zmysłu wzroku i słuchu, rozpoznawanych i identyfikowanych jako nowe, ciekawe, godne uwagi ${ }^{15}$. Stąd też aktywność poznawcza znajduje wyraz m.in. w samodzielnym odbieraniu wrażeń, percepcji, myśleniu, analizowaniu, rozpoznawaniu, identyfikowaniu, wybiórczym przetwarzaniu informacji, tworzeniu nowych, umysłowych reprezentacji świata, przekształcaniu dostępnych informacji, projektowaniu rozwiązań, werbalizowaniu własnych sądów i decyzji, zapamiętywaniu $^{16}$. Aktywności poznawczej towarzyszą procesy sensoryczne ${ }^{17}$ i percepcyjne ${ }^{18}$.

${ }^{11}$ Szerzej na ten temat piszą m.in. J. Szpet: Dydaktyka katechezy. Poznań 1999 s. 101-103; M Śnieżyński: Dydaktyka dialogu. Kraków 2001 s. 105-114.

${ }^{12}$ Tamże.

${ }^{13}$ H. Micińska: W poszukiwaniu inspiracji, czyli jak rozwijać aktywność poznawcza dziecka? http://www.uniwersytet-dzieciecy.pl/files/document/03a5db52dce3ceb0b813daf31f0ae16c139825 1416.pdf (dostęp: 3.06.2016).

${ }^{14}$ Tamże; por. A. Gurycka: Przeciw nudzie: o aktywności. Warszawa 1977.

${ }^{15}$ Tamże; A. Basińska: Aktywność poznawcza dziecka w przestrzeni edukacyjnej środowiska. https:// repozytorium.amu.edu.pl/bitstream/10593/459/1/Anna_Basi\%C5\%84ska.pdf (dostęp: 6.06.2016) s. 24-26.

16 Tamże.

17 Tego rodzaju procesy polegają na odbiorze sygnałów, które dopływają do osoby $\mathrm{z}$ otoczenia lub z jej własnego ciała. Ich odbiór ma miejsce $\mathrm{w}$ tak zwanych analizatorach. Zob. więcej o tym np. Procesy poznawcze. http://www.szkolnictwo.pl/szukaj,Procesy_poznawcze (dostęp: 6.06.2016).

${ }^{18}$ Mianem procesów percepcyjnych określa się złożone procesy spostrzegania, w wyniku których człowiek w sposób twórczy odbiera informacje z otoczenia, przetwarza je w umyśle, organi- 
Powszechnie utożsamia się ją $\mathrm{z}$ czynnościami, które człowiek podejmuje $\mathrm{w}$ związku $\mathrm{z}$ funkcjonowaniem i orientacją w środowisku oraz zdobywaniem i przetwarzaniem informacji i wiedzy ${ }^{19}$. Właśnie aktywność poznawcza umożliwia wielostronne uczenie się, wzbogacanie doświadczenia oraz porozumiewanie $\mathrm{z}$ innymi ${ }^{20}$. Co więcej, służy zaspokajaniu potrzeb poznawczych, rozwiązywaniu problemów i wykonywaniu zadań o charakterze poznawczym. U jej podstaw znajduje się m.in. ciekawość poznawcza ${ }^{21}$, konflikt informacyjny ${ }^{22}$ i konflikt poznawczy ${ }^{23}$. Niemniej istotą funkcję w pobudzaniu aktywności poznawczej spełniają nagrody i zewnętrzne sankcje, takie jak np. kary stosowane przez rodziców lub nauczycieli wobec dziecka za brak podstawowej wiedzy i błędne wykonanie zadania ${ }^{24}$. $\mathrm{Z}$ uwagi na typ podejmowanego działania związanego $\mathrm{z}$ zaspokajaniem potrzeb poznawczych, rozwiązywaniem problemów i wykonywaniem zadań o charakterze poznawczym badacze wyodrębniają aktywność poznawczą orientacyjną $^{25}$. Znajduje ona wyraz w zmysłowym poznaniu bodźców. W tego rodzaju aktywności poznawczej człowiek angażuje zmysł wzroku i słuchu oraz podejmuje szereg czynności werbalnych, do których zalicza się m.in. stawianie pytań, poszukiwanie odpowiedzi, wymianę informacji, udzielanie odpowiedzi, formułowanie własnych sądów ${ }^{26}$. Drugi rodzaj aktywności poznawczej wiąże się z działalnością badawczą. Ukierunkowany jest na poznawanie różnych zjawisk

zuje i przekształca. $Z$ tak rozpoznanych elementów powstaje uporządkowana całość, wpływająca na zachowanie człowieka. Zasadniczą rolę w wyżej określonych procesach percepcyjnych odgrywają wytworzone na podstawie uprzedniego doświadczenia wewnętrzne wzorce (reprezentacje i schematy poznawcze) rzeczywistości. W miarę wzbogacania wiedzy osobistej człowieka podlegają one weryfikacji, wzbogaceniu i przekształcaniu w nowe reprezentacje i schematy. Zob. więcej o tym np. w: tamże, Procesy poznawcze. https://pl.wikipedia.org/wiki/Procesy_poznawcze (dostęp: 6.06.2016).

${ }^{19}$ Basińska, dz. cyt., s. 24-26.

${ }^{20}$ Tamże.

${ }^{21}$ Termin ten zwykle wskazuje na wrodzoną zdolność związaną z potrzebą poszukiwania nowej wiedzy i aktywnego jej przyswajania, a tym samym na potrzebę podejmowania aktywności poznawczej. Zob. np. Gurycka, jw. s. 38

${ }^{22} \mathrm{~W}$ ogólnym rozumieniu konflikt informacyjny wskazuje na subiektywnie odczuwany stan niezgodności pomiędzy dwiema informacjami, który motywuje człowieka do aktywności poznawczej w celu konfrontowania sprzecznych informacji. Zob. o tym np. w: tamże; J. Morawiec: Konflikt informacyjny i ciekawość poznawcza. http://jolantamorawiec.blogspot.com/2012/05/konfliktinformacyjny-i-ciekawosc.html (dostęp: 7.06.2016).

${ }^{23}$ Termin ten oznacza stan, w którym człowiek rozpoznaje, że jego dotychczasowa wiedza nie zgadza się z nowymi treściami i doświadcza sprzeczności pomiędzy poszczególnymi fragmentami. Przezwyciężenie konfliktu poznawczego wymaga aktywności poznawczej, dzięki której można odkrywać nową wiedzę, uzupełniać i modyfikować dotychczasową, a przez to poszerzać zasób wiadomości. Zob. więcej o tym np. w: L. Budzińska: Konflikt poznawczy. Prawo ucznia do błędu. http://www.sp11.suwalki.pl/publikacje/publ_budz2.htm (dostęp: 7.06.2016); por. Basińska, jw. s. 24.

\footnotetext{
${ }^{24}$ Tamże; Z. Włodarski: Psychologia uczenia się. T. 1. Warszawa 1996 s. 336-340.

${ }^{25}$ Micińska, dz. cyt., s. 4-5.

${ }^{26}$ Tamże; Włodarski, dz. cyt., s. 243-263.
} 
niematerialnych (np. psychicznych, filozoficznych, religijnych) ${ }^{27}$. Wyraża się zatem $\mathrm{w}$ aktywności poznawczej o charakterze badawczym. Tego rodzaju aktywność polega na: 1) dostrzeganiu problemu; 2) analizowaniu informacji pochodzących z wielu źródeł; 3) ocenianiu; 4) porównywaniu, różnicowaniu, łączeniu wyodrębnionych elementów; 5) wytwarzaniu pomysłów nie tylko w oparciu o aktualnie rozpoznawane zjawiska, ale także w oparciu o uprzednio zdobytą, wzbogaconą o doświadczenie wiedzę osobistą; 6) weryfikowaniu pomysłów ${ }^{28}$.

Jednym z istotnych elementów, decydujących o właściwym rozumieniu aktywności poznawczej, jest sposób jej wyrażania. W trakcie tego rodzaju aktywności człowiek podejmuje czynności zewnętrzne i wewnętrzne. Znajdują one wyraz m.in. w przetwarzaniu informacji, eksperymentowaniu, rozwiązywaniu problemów, poszukiwaniu nowych informacji, definiowaniu, pisaniu, rozmowie, dyskusji, dochodzeniu do nowych stwierdzeń, tworzeniu skojarzeń, porównywaniu, klasyfikowaniu, obserwacji zjawisk, czytaniu, dokonywaniu pomiarów, szukaniu powiązań, grupowaniu treści, porównywaniu informacji, nazywaniu spostrzeżeń, oczekiwań oraz formułowaniu pytań, własnych sądów, przekonań i zamierzeń ${ }^{29}$. Wymienione czynności poznawcze wskazują na szerokie spectrum aktywności człowieka, które, chociaż trudne do zmierzenia, w dłuższej perspektywie przynoszą wymierne efekty, widoczne w zachowaniu, postrzeganiu rzeczywistości oraz w sposobie negocjowania znaczeń i rozwiązywania problemów.

\section{Zaangażowanie rodziców w proces stymulowania aktywności poznawczej dziecka}

Powszechnie wiadomo, że dziecko od początku istnienia, już w okresie prenatalnym, podlega bodźcom zewnętrznym, które w znacznym stopniu determinują jego integralny rozwój. W tym procesie oddziaływania szczególne miejsce zajmują rodzice. Ich postawa i zachowanie, a zwłaszcza bezpośrednie (werbalne i niewerbalne) kontakty z dzieckiem i między sobą, odnoszenie się do innych członków rodziny i znajomych oraz atmosfera wychowawcza, zaangażowanie społeczne rodziców, ich zainteresowania, umiejętności współdziałania, wykształcenie, preferowane wartości życiowe pozostają w ścisłym związku z aktywnością poznawczą dziecka ${ }^{30}$. To właśnie rodzice bezpośrednio lub pośrednio, świadomie, celowo i w sposób zaplanowany lub nieświadomie, samorzutnie, w sposób przygodny uczestniczą $\mathrm{w}$ tworzeniu warunków wspierających integralny rozwój dziecka, w którym ważne miejsce zajmuje kształtowanie umiejętności postrzega-

${ }^{27}$ Basińska, dz. cyt., s. 24-25.

${ }^{28}$ Tamże; Włodarski, dz. cyt.

${ }^{29}$ Tamże.

${ }^{30}$ M. Przetacznik-Gierowska, Z. Włodarski: Psychologia wychowawcza. T. 2. Warszawa 2014 s. 112-121. 
nia, zapamiętywania i przetwarzania informacji dochodzących z otoczenia ${ }^{31}$. Ich zaangażowanie $\mathrm{w}$ proces wspierania dziecka $\mathrm{w}$ aktywności poznawczej jest wielorakie i dynamiczne. Zmienia się wraz z rozwojem dziecka. Na przykład w wieku przedszkolnym stwarzanie dziecku okazji do swobodnej, spontanicznej zabawy i kreowania podczas niej rzeczywistości sprzyja nabywaniu nowych właściwości poznawczych ${ }^{32}$. Z kolei w wieku szkolnym umożliwianie dziecku udziału w zajęciach pozalekcyjnych, które go interesują, przyczynia się do zaspokajania podstawowych potrzeb rozwojowych ${ }^{33}$. Wymaga jednak od rodziców zachowania umiaru i zdrowego rozsądku oraz wolności wobec typowej dla społeczeństwa ponowoczesnego mody na udział dzieci w wielu zajęciach dodatkowych ${ }^{34}$. Dziecko potrzebuje bowiem czasu na odpoczynek w domu i kontakty towarzyskie $\mathrm{z}$ rówieśnikami ${ }^{35}$. Niemniej istotne jest też stwarzanie okazji do rozwoju zainteresowań czytelniczych ${ }^{36}$. Bezpośredni kontakt z książką rozwija wrażliwość estetyczną, kształtuje wyobraźnię i kreatywność, dostarcza pozytywnych emocji, pobudza do samodzielnego myślenia, wzbogaca zasób słownictwa, dostarcza informacji o świecie oraz przyczynia się do rozwoju sfery moralnej ${ }^{37}$. Zaspokaja też potrzeby estetyczne i społeczne ${ }^{38}$, wskazuje na wzorce zachowań i stwarza wiele okazji do utożsamiania się z bohaterami literackimi ${ }^{39}$. Nie może jednak zastąpić bezpośrednich kontaktów interpersonalnych z rodzicami i rówieśnikami.

W stymulowaniu aktywności poznawczej dziecka rodzice pełnią szczególną funkcję. Uczestniczą bowiem w wyjątkowych, niepowtarzalnych i specyficznych interakcjach społecznych $z$ dzieckiem ${ }^{40}$. Jako osoby bardziej kompetentne, odpowiedzialne za wychowanie, są zobowiązani do tworzenia zewnętrznego kon-

31 Tamże

32 E. Lubianiec: „Inwestycje edukacyjne” - jak zagospodarować czas wolny dziecka. http://www.szkolnictwo.pl/index.php?id=PV0098 (dostęp: 10.06.2016).

33 Tamże.

${ }^{34}$ Zob. więcej o tym np. w: A. Brzezińska: Czy i kiedy zapisać dziecko na zajęcia dodatkowe?.http://acpir.swps.pl/index.php/psychoniezbednik/17-czytelnia/113-czy-i-kiedy-zapisac-dzi ecko-na-zajecia-dodatkowe (dostęp: 11.06.2016); A. Wirtwein-Przerwa: Zajęcia dodatkowe tresura od małego?. http://www.edziecko.pl/pierwszy_rok/1,79404,7195399,Zajecia_dodatkowe_ tresura_od_malego_.html (dostęp: 11.06.2016).

${ }^{35}$ Tamże.

${ }^{36}$ Zob. więcej o tym np. w: K. Curkowska: Literatura dla dzieci-uczy, bawi, wychowuje. W: Wychowanie dzieci w wieku przedszkolnym. Red. E. Osewska, J. Stala. Tarnów 2005 s. 71-99; K. Jakubczyk: Bajkoterapia jako metoda pracy z dzieckiem $w$ wieku przedszkolnym. „Nauczyciel i Szkoła" 2013 nr 1 s. 249-258.

37 Tamże.

38 Tamże.

39 Tamże.

${ }^{40}$ M. Dziewiecki: Rodzice, wychowanie, powołanie. „Zeszyty Formacji Katechetów” 7: 2007 nr 4 s. $12-16$ 
tekstu aktywności poznawczej dziecka ${ }^{41}$. Stają się organizatorami przestrzeni społecznej i edukacyjnej, która pozwala dziecku w sposób aktywny zdobywać nowe wiadomości i sprawności umysłowe (np. umiejętność formułowania pytań, własnych sądów i przekonań oraz rozwiązywania problemów) ${ }^{42}$. To, w jaki sposób rodzice angażują się w realizację tego zadania, uwidacznia się w ich postawie, wypowiedziach, zachowaniu ${ }^{43}$. Zależy jednak od wielu czynników (m.in. od wykształcenia rodziców, poziomu kultury pedagogicznej, wzorców spędzania czasu wolnego w rodzinie, sytuacji materialnej rodziny, dążeń i aspiracji rodziców) ${ }^{44}$. Wymiernym wyrazem tego zaangażowania jest aktywność dziecka oraz jego postępy związane ze zdobywaniem wiedzy o rzeczywistości i rozwijaniem umiejętności społecznych ${ }^{45}$.

Niewątpliwie tempo rozwoju poznawczego dziecka, zwłaszcza w okresie przedszkolnym, zależy $\mathrm{w}$ znacznym stopniu od wrodzonych predyspozycji ${ }^{46}$. Bodźce zewnętrzne, pochodzące od rodziców i wychowawców, pobudzają dziecko do poznawania i rozumienia rzeczywistości oraz rozwijania umiejętności i zainteresowań ${ }^{47}$. Stąd też ważne są zróżnicowane, dostosowane do wieku i możliwości rozwojowych, sposoby stymulowania aktywności poznawczej, które mają na celu rozbudzenie w dziecku ciekawości poznawczej i kształtowanie aspiracji edukacyjnych ${ }^{48}$. Składają się na nie nie tylko odpowiednio dobrane zabawki, gry, książki i filmy, ale także wspólnie spędzany czas na zabawie, rozmowach, tworzeniu nowych pomysłów oraz udział w imprezach kulturalnych i korzystanie $\mathrm{z}$ ofert edukacyjnych ${ }^{49}$. Niemniej istotną rolę odgrywa atmosfera wychowawcza w rodzinie oparta na życzliwości i akceptacji dziecka (jego umiejętności, podejmowanych prób i błędów) $)^{50}$. W praktyce trudno zmierzyć i ocenić, na ile atmosfera wychowawcza w rodzinie przyczynia się do skutecznej stymulacji aktywności dziecka. Należy ona do tych elementów, które mimo że nie są wymierne, to przyczyniają się do wzmocnienia w dziecku samooceny $\mathrm{i}$ wiary w siebie. Odwołując się do dostrzeganych postępów i sukcesów dziecka w zakresie poszerzania wiedzy o rzeczywistości i rozwijania umiejętności, rodzice mogą inicjować nowe sytuacje społeczno-edukacyjne, które pobudzają dziecko do aktywności poznaw-

${ }^{41}$ A. Szewczyk: Rodzice w procesie wspierania twórczej aktywności dziecka. „Studia Pedagogiczne (Kielce)" T. 21: 2012 s. 89-97.

${ }^{42}$ Tamże.

${ }^{43}$ Tamże.

${ }^{44}$ Basińska, dz. cyt. s. 82 i nn.

${ }^{45}$ Tamże.

46 J. Andrzejewska: Aktywność poznawcza dziecka. „Wychowanie w Przedszkolu” 2014 nr 7 s. $5-9$.

${ }^{47}$ Tamże.

${ }^{48}$ Tamże.

${ }^{49}$ Basińska, dz. cyt. s. 82 i nn.

${ }^{50}$ E. Uchmanowicz: Wychowanie $w$ rodzinie a ksztaltowanie się osobowości dziecka. „Wychowawca" 2014 nr 3 s. 8-10. 
czej. Zwykle dokonuje się to za pomocą zróżnicowanych oddziaływań. Do nich zalicza się tworzenie dziecku przestrzeni do zabawy, korzystania $\mathrm{z}$ mediów w sposób kontrolowany i selektywny (np. w celu znalezienia konkretnych informacji, oglądania programów i filmów edukacyjnych, a następnie przedyskutowania podejmowanych $\mathrm{w}$ nich zagadnień), poszerzania wiedzy o świecie w czasie wypoczynku, odkrywania nowych miejsc i treści kultury, zdobywania nowych umiejętności (np. gotowania, szycia) $)^{51}$. Ważną funkcję spełnia też spokojna rozmowa z dzieckiem oraz współpraca rodziców z przedszkolem i szkołą. Nauczyciele mogą dostarczać rodzicom nowych pomysłów w przełamywaniu rutyny i dokonywaniu wyboru zróżnicowanych form aktywności poznawczej dziecka oraz zachęcać do roztropnego i odpowiedzialnego korzystania z ofert edukacyjnych proponowanych w środowisku lokalnym (np. przez instytucje, organizacje, miejsca kreatywnej zabawy i nauki) ${ }^{52}$.

Wyżej wymienione działania rodziców w zakresie stymulowania aktywności poznawczej dziecka wymagają respektowania: zasady stopniowania trudności, zasady podążania za potrzebami i zainteresowaniami dziecka, zasady zachęcania dziecka do samodzielności w podejmowaniu nowych wyzwań oraz zasady współdziałania dziecka z innymi (np. rodzicami, krewnymi, rówieśnikami) i zasady dialogu ${ }^{53}$. Zasady te określają reguły postępowania $\mathrm{w}$ procesie wychowania. Ułatwiają dobór form i metod, które w sposób optymalny pobudzają dziecko do aktywności poznawczej. W znacznym stopniu warunkują zatem charakter podejmowanych przez rodziców działań w zakresie stymulowania aktywności poznawczej dziecka.

\section{Mocne i słabe strony zaangażowania rodziców}

Wyżej opisane kwestie wskazują na wielorakie aspekty zaangażowania rodziców w stymulowanie aktywności poznawczej dziecka. Coraz częściej można je dostrzec w codziennym życiu. Wybierając dla dzieci różne zajęcia dodatkowe (sportowe, językowe, teatralne, artystyczne), rodzice wspierają dzieci w poszerzaniu wiedzy o rzeczywistości i zdobywaniu nowych umiejętności ${ }^{54}$. Tym samym z jednej strony angażują się w rozwój poznawczy dziecka, z drugiej natomiast ograniczają swój własny, bezpośredni, oparty na dialogu i kontaktach interpersonalnych udział $\mathrm{w}$ stymulowaniu aktywności poznawczej dziecka. Co

${ }^{51}$ Basińska, dz. cyt. s. 25-27.

${ }^{52}$ Tamże.

${ }^{53}$ K. Wojtaś: Zajęcia dodatkowe: wsparcie rozwoju czy odbieranie dzieciństwa. http://www. mjakmama24.pl/dziecko/edukacja/zajecia-dodatkowe-wspracie-rozwoju-czy-odbieranie-dziecin stwa,563_4730.html (dostęp: 16.06.2016).

${ }_{54}$ K. Kowal: Zajęcia dodatkowe - im więcej obowiązów tym lepiej? https://akade miapuchatka.pl/pl/dla-rodzicow/zajecia-dodatkowe-im-wiecej-obowiazkow-tym-lepiej (dostęp: 15.06.2016). 
ważne, ograniczają dziecku czas na zwykłą, spontaniczną, tematyczną zabawę w domu i na świeżym powietrzu (np. w ogródku jordanowskim, na orliku) ${ }^{55}$. Pośrednio przyczyniają się w ten sposób do pomniejszania znaczenia spontanicznej, opartej na aktywności własnej, kreatywności. Niekiedy też hamują twórcze zachowania dziecka.

W praktyce trudno określić wymierne efekty zaangażowania rodziców w stymulowanie aktywności poznawczej potomstwa. Nadmiar zajęć dodatkowych czy też przerost ambicji rodziców nad potrzebami i zainteresowaniami dziecka może przyczyniać się do deformacji osobowości, destrukcyjnych zachowań (np. odwlekania wyjścia z domu na zajęcia, podatności na infekcje, trudności z podejmowaniem decyzji), które są reakcją na zmęczenie i przeciążenie obowiązkami $^{56}$. Niejednokrotnie nadmiar zajęć dodatkowych, nawet jeśli dziecko chętnie w nich uczestniczy, a rodzice są przekonani, że w ten sposób dbają o dobro dziecka i jego „lepszy start w przyszłość”, dostarczając mu bodźców do aktywności poznawczej, prowadzi do zaburzeń w rozwoju osobowym i zachowaniu (np. apatii, agresji, chorób psychosomatycznych, wybuchów złości, kłopotów z porannym wstawaniem) ${ }^{57}$. Tym samym brak zdrowego rozsądku w stymulowaniu aktywności poznawczej dziecka okazuje się gorszy w skutkach niż małe zaangażowanie rodziców ${ }^{58}$, pomniejsza bowiem znaczenie zabawy w prawidłowym rozwoju dziecka, czyli naturalnej formy aktywności dziecka, sprzyjającej poznawaniu świata, nawiązywaniu i podtrzymywaniu kontaktów interpersonalnych i budowaniu więzi międzyludzkich ${ }^{59}$. Hamuje też rozwój twórczości i wyobraźni oraz uczenie się ról życiowych poprzez udział w zabawach tematycznych $^{60}$. Wzmacnia natomiast oczekiwania wobec innych osób. Dziecko uczy się, że to inni są zobowiązani do organizowania jego czasu, stwarzania mu przestrzeni do bycia aktywnym i zadowolonym, kontrolowania każdej aktywności i dostarczania nagród. Staje się też zależne od tego, w jaki sposób rodzice stymulują jego aktywność poznawczą. Nie ma możliwości doświadczania negatywnych skutków zachowań społecznie nieakceptowanych. Uczy się głównie realizacji zadań. Nie ma czasu na refleksję nad sobą i innymi osobami, co utrudnia dostęp do własnych uczuć, pragnień i potrzeb ${ }^{61}$.

55 A. Dyląg: Nadmiar zajęć dodatkowych szkodzi!. http://www.familie.pl/artykul/Nadmiarzajec-dodatkowych-szkodzi,3223,1.html (dostęp: 16.06.2016).

${ }^{56}$ Tamże.

${ }^{57}$ Kowal, dz. cyt.; Wojtaś, dz. cyt.; Zajęcia dodatkowe dla dzieci - inwestycja czy fanaberia?.http://www.zfilizankakawy.pl/2016/05/zajecia-dodatkowe-dla-dzieci-inwestycja.html. (dostęp: 17.06.2016).

${ }^{58}$ Dyląg, dz. cyt.; Kowal, dz. cyt.; Wojtaś, dz. cyt.

${ }^{59}$ Tamże.

${ }^{60}$ Tamże.

${ }^{61}$ Tamże. 
Codzienny udział dziecka $\mathrm{w}$ zajęciach dodatkowych, nawet jeśli są one zróżnicowane, uniemożliwia swobodne i dowolne spędzanie czasu wolnego, a przez to spontaniczne, zgodne $\mathrm{z}$ własnymi potrzebami i zainteresowaniami, poznawanie świata ${ }^{62}$. Co więcej, sprawia, że dziecko nie ma okazji do nawiązania przyjaźni z rówieśnikami poza przedszkolem lub szkołą. Staje się zależne wyłącznie od ambicji i decyzji rodziców, nawet jeśli ma możliwość wyboru zajęć. Zwykle rodzice tak prowadzą rozmowę z dzieckiem, że decyduje się ono na udział w zajęciach i wykazuje zainteresowanie ${ }^{63}$. Chcąc bowiem zaspokoić oczekiwania rodziców, dziecko aktywnie uczestniczy w zajęciach. Rodzice, mniej lub bardziej świadomie, stosują techniki manipulacji. W konsekwencji przyczyniają się z jednej strony do lepszego przystosowania dziecka do zajęć zorganizowanych i sumiennego wypełniania poleceń osoby prowadzącej, $z$ drugiej natomiast pozbawiają dziecko swobody i kreatywności w planowaniu zabawy ${ }^{64}$. Co ważne, tego rodzaju zachowania rodziców mogą sprawić, że dziecko, które obecnie ma każdego dnia zorganizowane zajęcia, w przyszłości nie będzie potrafiło samodzielnie podejmować ważnych decyzji, nawiązywać prawidłowych kontaktów interpersonalnych oraz negocjować w sytuacjach konfliktowych (np. w rodzinie, w pracy) i nie będzie chciało spędzać wolnego czasu z rodzicami ${ }^{65}$.

Świadome zaangażowanie rodziców w stymulowanie aktywności poznawczej dziecka wymaga zatem nie tylko odpowiedniej wiedzy pedagogicznej, ale także umiejętności wyselekcjonowania zajęć i krytycznego, a zarazem odpowiedzialnego korzystania z ofert edukacyjnych, książek, materiałów i gier edukacyjnych. Istotna wydaje się również zdolność do nieulegania charakterystycznej dla ponowoczesności modzie na zajęcia dodatkowe oraz przekładania własnych ambicji na dziecko. Dzięki temu można uniknąć sytuacji, w której dziecko codziennie, od poniedziałku do niedzieli, uczestniczy w zajęciach poza przedszkolem lub szkołą.

\section{Konkluzja}

Niewątpliwie rodzice odgrywają ważną, (nie)wymierną rolę w stymulowaniu aktywności poznawczej dziecka. Ich świadome, odpowiedzialne i mądre zaangażowanie $\mathrm{w}$ integralny rozwój potomka w znacznym stopniu decyduje o wymiernych efektach wychowania i edukacji, uwidocznionych w aktywności zewnętrznej, wiedzy i umiejętnościach dziecka. Jednakże nawet najlepsze, interesujące i aktywizujące zajęcia dodatkowe (poza przedszkolem i szkołą) nie zastąpią bezpośredniego kontaktu rodziców z dzieckiem oraz swobodnej i kreatywnej

\footnotetext{
62 Tamże.

63 Tamże.

64 Tamże.

65 Tamże.
} 
zabawy w domu i na świeżym powietrzu. Chodzi tu zwłaszcza o czas poświęcony na wspólną aktywność, odpoczynek, rozmowy, oglądanie filmów razem, gry planszowe, twórcze zabawy tematyczne $\mathrm{w}$ domu i na świeżym powietrzu oraz możliwość częstych kontaktów z rówieśnikami w domu i na placu zabaw.

W odpowiedzialnym stymulowaniu aktywności poznawczej dziecka pierwszoplanową rolę odgrywa zachowanie umiaru i złotego środka. Respektowanie tych zasad chroni rodziców przed przesadną koncentracją na dziecku, jego sukcesach i umiejętnościach oraz przed próbą przyśpieszenia jego wszechstronnego rozwoju i przed zawyżonymi oczekiwaniami. Pozwala właściwie stymulować aktywność poznawczą dziecka, bez pomijania jego prawa do radosnego dzieciństwa i kształtowania więzi emocjonalnej z rodzicami.

\section{Bibliografia}

Andrzejewska J.: Aktywność poznawcza dziecka. „Wychowanie w Przedszkolu” 2014 nr 7 s. 5-9. Basińska A.: Aktywność poznawcza dziecka w przestrzeni edukacyjnej środowiska. https:// repozytorium.amu.edu.pl/bitstream/10593/459/1/Anna_Basi\%C5\%84ska.pdf (dostęp: 6.06.2016) s. 24-26.

Brzezińska A.I. (Red.): Psychologiczne portrety człowieka. Praktyczna psychologia rozwojowa. Gdańsk 2005.

Brzezińska A.: Czy i kiedy zapisać dziecko na zajęcia dodatkowe?. http://acpir.swps.pl /index.php/psychoniezbednik/17-czytelnia/113-czy-i-kiedy-zapisac-dziecko-na-zajecia-dodatkowe (dostęp: 11.06.2016).

Budzińska L.: Konflikt poznawczy. Prawo ucznia do błędu. http://www.sp11.suwalki. pl/publikacje/publ_budz2.htm (dostęp: 7.06.2016).

Cudo A., Kopeć N., Sawicki K. (Red.): Rodzina wobec wyzwań współczesności. Lublin 2013. Marzec H., Szymczyk K. (Red.): Rodzina w obliczu wspótczesnych wyzwań cywilizacyjnych. T. 1. Piotrków Trybunalski 2013.

Curkowska K.: Literatura dla dzieci - uczy, bawi, wychowuje. W: Wychowanie dzieci w wieku przedszkolnym. Red. E. Osewska, J. Stala. Tarnów 2005 s. 71-99.

Dudek A.J.: Chiński, joga i szachy - przedszkola kusza zajęciami dodatkowymi, by dać dzieciom „lepszy start”. http://natemat.pl/115069,chinski-joga-i-szachy-przedszkola-kusza-zajeciami-dodat kowymi-by-dac-dzieciom-lepszy-start (dostęp: 30.05.2016).

Dudziak U.: Życie, rodzina, wychowanie. Warszawa 2009.

Dyląg A.: Nadmiar zajęć dodatkowych szkodzi!. http://www.familie.pl/artykul/Nadmiar-zajecdodatkowych-szkodzi,3223,1.html (dostęp: 16.06.2016).

Dziewiecki M.: Rodzice, wychowanie, powołanie. „Zeszyty Formacji Katechetów” 7: 2007 nr 4 s. $12-16$.

Gurycka A.: Przeciw nudzie: o aktywności. Warszawa 1977.

Guz S., Sokołowska-Dzioba T., Pielecki A. (Red.): Aktywność dzieci i młodzieży. Warszawa 2008. http://sjp.pwn.pl/slowniki/stymulowa\%C4\%87.html (dostęp: 1.06.2016).

Jakubczyk K.: Bajkoterapia jako metoda pracy z dzieckiem $w$ wieku przedszkolnym. „Nauczyciel i Szkoła" 2013 nr 1 s. 249-258.

Jeziorański M., Opozda D., Rynio A. (Red.): Rodzina przestrzenia rozwoju osoby: perspektywa pedagogiczna. Lublin 2012. 
Kowal K.: Zajęcia dodatkowe - im więcej obowiązów, tym lepiej?. https://akademiapuchat ka.pl/pl/dla-rodzicow/zajecia-dodatkowe-im-wiecej-obowiazkow-tym-lepiej. (dostęp: 15.06.2016). Lubianiec E.: „Inwestycje edukacyjne” - jak zagospodarować czas wolny dziecka. http://www. szkolnictwo.pl/index.php?id=PV0098 (dostęp: 10.06.2016).

Lubina E. (Red.): Rodzina w pierwszym dwudziestoleciu XXI wieku: problemy stare i nowe. Lublin 2013.

Micińska H.: $W$ poszukiwaniu inspiracji, czyli jak rozwijać aktywność poznawcza dziec$k a$ ?.http://www.uniwersytet-dzieciecy.pl/files/document/03a5db52dce3ceb0b813daf31f0ae16c139 8251416.pdf (dostęp: 3.06.2016).

Morawiec J.: Konflikt informacyjny $i$ ciekawość poznawcza. http://jolantamorawiec.blogspot. com/2012/05/konflikt-informacyjny-i-ciekawosc.html (dostęp: 7.06.2016).

Muchacka B. (Red.): Rodzina w kontekście współczesnych problemów wychowania. Kraków 2008 Muchacka B.: Stymulowanie aktywności poznawczej dzieci w przedszkolu. Kraków 2000.

Pikuła N. (Red.): Rodzina podmiotem wychowania i kreatorem komunikacji społecznej. Kraków 2010.

Procesy poznawcze. http://www.szkolnictwo.pl/szukaj,Procesy_poznawcze (dostęp: 6.06.2016).

Procesy poznawcze. https://pl.wikipedia.org/wiki/Procesy_poznawcze (dostęp: 6.06.2016).

Przetacznik-Gierowska M., Włodarski Z.: Psychologia wychowawcza. T. 2. Warszawa 2014.

Przybysz A. (Red.): Aktywność poznawcza podmiotu w perspektywie badań kognitywistycznych. Poznań 2015

Sikorska I.: Rozwój dziecka w przedszkolu. Stymulujące właściwości wybranych systemów edukacyjnych. Kraków 2010.

Szewczyk A.: Rodzice w procesie wspierania twórczej aktywności dziecka. „Studia Pedagogiczne (Kielce)" T. 21: 2012 s. 89-97.

Szpet J.: Dydaktyka katechezy. Poznań 1999.

Śnieżyński M.: Dydaktyka dialogu. Kraków 2001

Uchmanowicz E.: Wychowanie w rodzinie a kształtowanie się osobowości dziecka. „Wychowawca” 2014 nr 3 s. 8-10.

Wirtwein-Przerwa A.: Zajęcia dodatkowe - tresura od małego?.http://www.edziecko.pl/ pierwszy_rok/1,79404,7195399,Zajecia_dodatkowe_tresura_od_malego_.html (dostęp: 11.06.2016).

Włodarski Z.: Psychologia uczenia się. T. 1. Warszawa 1996.

Wojtaś K.: Zajęcia dodatkowe: wsparcie rozwoju czy odbieranie dzieciństwa. http://www.mjak mama24.pl/dziecko/edukacja/zajecia-dodatkowe-wspracie-rozwoju-czy-odbieranie-dziecinstwa, 563_4730.html (dostęp: 16.06.2016).

Zajęcia dodatkowe dla dzieci - inwestycja czy fanaberia?. http://www.zfilizankakawy.pl/ 2016/05/zajecia-dodatkowe-dla-dzieci-inwestycja.html. (dostęp: 17.06.2016).

\section{STRESZCZENIE}

\section{[Nie]wymierna rola rodziców w stymulowaniu aktywności poznawczej dziecka}

W ostatnich latach, pod wpływem przemian kulturowych i społecznych, zmienia się jakość i forma zaangażowania rodziców w stymulowanie aktywności poznawczej dzieci $\mathrm{W}$ celu spełnienia wymagań społecznych i kulturowych, rodzice często angażują się w poszukiwanie innowacyjnych form kształcenia. Sięgają przy tym do bardzo zróżnicowanych jakościowo propozycji, proponowanych w mediach i oferowanych przez niektórych nauczycieli czy psychologów. Zaangażowanie rodziców w pobudzaniu aktywności poznawczej ich dziecka jest jednak procesem bardzo złożonym, który w życiu codziennym napotyka różne ograniczenia i utrudnienia. Wynikają one z przemian wychowawczych, mniejszej ilości czasu spędzanego razem, zmniejszonej dzietności rodzin, szybkości życia, braku czasu czy z tendencji rodziców do stawiania nieadekwatnych do możliwości 
dziecka wymagań. Stymulowanie aktywności poznawczej dziecka w takich uwarunkowaniach nie zawsze przynosi oczekiwane rezultaty, adekwatne do zainwestowanych środków. Jest to szczególnie istotne w sytuacjach, gdy rodzice rezygnują z prostych, tradycyjnych, sprawdzonych metod wspierania ich dziecka w rozwoju poznawczym i sugerują się nowymi trendami, dążąc niekiedy do zaspokojenia własnych, nadmiernych ambicji. Wybór konkretnych form stymulowania aktywności poznawczej dziecka i postawa rodziców warunkują w dużym stopniu nie tylko jakość działań, ale także ich efektywność.

Słowa kluczowe: rodzice, wychowanie, dziecko, aktywność poznawcza, pedagogika, edukacja.

\section{SUMMARY \\ [Im]measurable Role of Parents in Stimulating the Cognitive Activity of Children}

In recent years, under the influence of cultural and social transformations, the quality and form of parental involvement in stimulating the cognitive activity of children has been changing. In meeting social and cultural demands, parents often engage in searching for innovative forms of education. They are increasingly often guided by trends and popularity, abandoning traditional methods of supporting children in their cognitive development. Therefore, parents often choose modern proposals, diversified in terms of quantity and quality, advertised in the mass media and promoted by teachers, psychologists and sometimes also by their acquaintances.

Parents' involvement in stimulating the cognitive activity of their child is a complex process, which encounters various limitations and impediments in everyday life. They result, among others, from diminishing the role of play in the family, of free time spent together, from reducing the number of children in the family to only one, from a high speed of life, the domination of new information and communication technologies, a lack of time, following the trends, excessive, parental ambitions inadequate to the child's capabilities, their requirements towards the child and realization of their own dreams. Under such conditions, stimulating the cognitive activity of a child does not always bring expected results that are directly proportional to time and money invested. On the contrary, it is often difficult for parents to see clear, measurable effects. This is particularly true in situations when parents resign from simple, traditional, proved methods of supporting their child in cognitive development and follow fashion, striving for satisfaction of their own, excessive ambitions.

The choice of specific forms of stimulating cognitive activity of a child and parents' approach determine, to a high extent, not only the quality of their role in this process, but also the efficiency of undertaken activities.

Keywords: parents, upbringing, children, cognitive activity, pedagogy, education. 